\author{
Volume 2 omor 1, Februari,
}

MULTIKARYA KONS

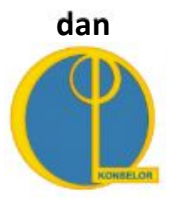

Ikatan Konselor Indonesia (IKI)

\title{
Konsep Diri Remaja pada Masa Pubertas dan Implikasinya terhadap Layanan Bimbingan dan Konseling
}

Juliana, Indra Ibrahim \& Afrizal Sano

Universitas Negeri Padang

\begin{abstract}
For students who are in puberty, they should have a self-concept in the face of changes experienced during puberty. Where they should have the knowledge, hope, and an assessment of the rapid body changes that occur at that time. But the facts on the ground, from observations and interviews that there are students who do not have a good self-concept in the face of puberty. This study classified the type of descriptive quantitative research. Research subjects were 79 students in the class VII puberty in SMP 13 Sijunjung. The research instrument is the questionnaire. Research findings reveal: in general students have a good self-concept in the face of puberty.
\end{abstract}

Keyword: Self-concept, students at puberty

Copyright ( 2014 IICE - Multikarya Kons (Padang - Indonesia) dan IKI - Ikatan Konselor Indonesia - All Rights Reserved

Indonesian Institute for Counseling and Education (IICE) Multikarya Kons

\section{PENDAHULUAN}

Masa remaja adalah masa yang berada dalam fase perkembangan yang pertumbuhannya sangat pesat. Pada masa ini bagian-bagian tertentu dari seorang individu sudah semakin kuat dan semakin menarik. Remaja sudah mulai mampu berfikir abstrak dan memecahkan masalah yang bersifat hipotesis. Hal ini diperkuat oleh Mohammad Ali dan Asrori (2009:10) bahwa pada masa remaja memungkinkan bagi remaja untuk mampu berfikir secara lebih abstrak, dan menguji hipotesis.

Masa remaja merupakan salah satu tahap di dalam kehidupan manusia yang sangat kritis, karena masa remaja ini merupakan tahap transisi dari masa kanak-kanak ke masa dewasa. Pada tahap ini banyak sekali terjadi perubahan pada diri remaja tersebut, baik itu perubahan fisik, emosional maupun sosial. Masa perubahan seperti ini biasa juga disebut sebagai masa puber. Sebagaimana diungkapkan oleh Elida Prayitno (2006:19) bahwa "pertumbuhan yang sangat cepat merupakan karakteristik pertumbuhan pada periode remaja. Pertumbuhan yang sangat cepat terutama terjadi pada periode awal masa remaja yang disebut pubertas".

Pubertas adalah periode yang unik dan khusus yang ditandai oleh perubahan-perubahan perkembangan tertentu yang tidak terjadi dalam tahap-tahap lain dalam rentang kehidupan. Masa puber juga dianggap sebagai periode tumpang tindih karena mencakup tahun-tahun akhir masa kanak-kanak dan tahun-tahun awal masa remaja.

Masa puber merupakan awal penting yang menandai masa remaja. Sebagaimana diungkapkan oleh John W. Santrock (2007:83) bahwa Pubertas (puberty) adalah sebuah periode dimana kematangan fisik berlangsung pesat yang melibatkan perubahan hormonal dan tubuh, yang terutama berlangsung di masa remaja awal.

Perubahan yang dialami remaja pada masa puber sering merisaukannya. Karena mereka menganggap bahwa perubahan-perubahan yang terjadi tersebut sebagai suatu kejanggalan yang sangat mengganggu, yang mempengaruhi semua bagian tubuh, baik di dalam maupun di luar tubuh. Sesuai dengan yang dinyatakan Elizabeth B. Hurlock (1980:191)"pertumbuhan fisik yang pesat cenderung disertai kelelahan, kelesuan, dan perubahan-perubahan kelenjer internal remaja pubertas sering terganggu dengan perubahan ini”. Selain perubahan psikis, perubahan ukuran tubuh juga menyebabkan kecanggungan bagi remaja 
pubertas, sebab mereka harus menyesuaikan diri dengan perubahan-perubahan yang terjadi pada dirinya. Perubahan ukuran dan proporsi tubuh yang terjadi sangat mencolok sehingga keseimbangan yang sebelumnya sudah terbentuk mempengaruhi sikap dan tingkah laku remaja pubertas.

Masa puber anak laki-laki berbeda dengan masa puber anak perempuan. Menurut Elizabeth B. Hurlock (1980:185) "masa puber anak perempuan berada pada rentangan umur 11 sampai umur 15 tahun, sedangkan masa puber anak laki-laki berada pada rentangan umur 12 sampai 16 tahun”. Dari pendapat di atas jelas terlihat bahwa anak perempuan lebih dulu mencapai kematangan daripada anak laki-laki. Dan dalam menghadapi masa puber ini para remaja diharapkan memiliki konsep diri yang baik.

Konsep diri menurut Epstein dkk (dalam Elida Prayitno, 2006: 121) mengungkapkan bahwa" konsep diri (self concept) sebagai pendapat atau perasaan atau gambaran seseorang tentang dirinya sendiri, baik yang menyangkut materi, fisik (tubuh), maupun psikis (sosial, emosional, moral, dan kognitif) yang dimiliki seseorang". Remaja pubertas yang mengalami pertumbuhan fisik yang sangat pesat tentunya akan memiliki pendapat tersendiri mengenai perubahan yang dialaminya tersebut.

Sebagai remaja pubertas yang baik, mereka diharapkan paham dengan adanya perubahan fisik yang mereka alami. Selain itu mereka juga tentunya punya harapan tersendiri terhadap pertumbuhan fisiknya. Sehingga hal itu akan melahirkan penilaian yang baik dari remaja pubertas tersebut terhadap perubahan yang dialaminya. Dengan begitu maka remaja pubertas akan memiliki konsep diri yang positif dalam hidupnya. Karena menurut James F. Calhoun (1995:67) konsep diri adalah pengetahuan seseorang tentang dirinya, pengharapan seseorang tentang dirinya, dan penilaian seseorang tentang dirinya

Fakta di lapangan berdasarkan observasi dan wawancara, melakukan observasi yang dilakukan pada tanggal 11 sampai 18 Juni 2012 di SMP N 13 Sijunjung. Observasi peneliti lakukan dengan cara masuk ke kelas saat siswa sedang belajar, dan juga dengan melihat siswa saat beraktifitas di luar kelas. Dari observasi yang dilakukan peneliti, ditemukan beberapa siswa perempuan maupun siswa laki-laki yang terganggu dengan perubahan yang terjadi pada dirinya. Misalnya siswa perempuan terlihat minder karena payudaranya yang sudah mulai tumbuh besar, sedangkan.

Sehingga untuk menyembunyikannya siswa perempuan ini sedikit membungkukkan bahunya untuk menutupi payudaranya. Demikian juga dengan siswa laki-laki yang terlihat tidak nyaman dengan perubahan suara, Sehingga enggan saat disuruh guru bicara di depan kelas. Siswa perempuan dan laki-laki juga mengalami masalah pada wajah mereka. Wajah mereka terlihat berminyak dan berjerawat.

Selain observasi, peneliti melanjutkan dengan melakukan wawancara di kelas pada tanggal 20 sampai 22 Juni 2012. Wawancara peneliti lakukan terhadap 10 orang siswa yang terlihat bermasalah dengan perubahan yang terjadi pada dirinya, serta pada siswa 10 orang siswa yang terlihat seperti tidak mengalami masalah dengan perubahan tersebut. Dari hasil wawancara tersebut. Peneliti mendapatkan informasi bahwasanya mereka sebenarnya tidak terlalu memahami perubahan-perubahan yang mereka alami, sehingga mereka menilai bahwa itu adalah sesuatu yang buruk yang terjadi pada diri mereka. Akibat adanya perubahan tersebut penampilan mereka menjadi terganggu.

Sedangkan dari hasil wawancara yang peneliti lakukan terhadap 10 orang siswa yang terlihat tidak bermasalah dengan perubahan yang dialaminya. Peneliti mendapat informasi bahwa bagi mereka perubahanperubahan yang mereka alami adalah hal yang baik bagi mereka. Karena mereka tahu bahwa itu merupakan tanda bahwa mereka bukan anak-anak lagi. Bahkan di antara mereka ada yang merasa lebih percaya diri dengan perubahan-perubahan yang mereka alami tersebut.

Selanjutnya, peneliti melanjutkan dengan melakukan wawancara pada tanggal 23 Juni 2012 di ruang BK SMP N 13 Sijunjung. Wawancara dilakukan terhadap 2 orang guru BK yang ada di sekolah tersebut. Berdasarkan hasil wawancara yang peneliti lakukan dengan guru BK di sekolah tersebut, didapatkan informasi bahwa pada umumnya siswa yang datang untuk konseling kepada guru BK adalah siswa yang bermasalah dengan perubahan yang terjadi pada dirinya. Ada siswa laki-laki yang merasa bingung saat pertama kali mengalami mimpi basah. Mereka juga terganggu dengan suaranya yang berubah menjadi besar, serta wajah mulai berminyak dan mulai ditumbuhi jerawat. Dan ada juga siswa perempuan yang mengaku takut saat pertama kali menstruasai. Mereka juga merasa risih dengan bentuk tubuhnya yang mulai berubah, sehingga membuat pakaian mereka menjadi terasa sempit. Hal ini membuat mereka merasa malu dengan keadaan tersebut.

Dalam upaya penyelesaian masalah konsep diri remaja pada masa pubertas, guru BK memiliki peran yang cukup besar karena salah satu tugas guru BK adalah menyelesaikan KES-T (Kehidupan Efektif Sehari-hari 
Terganggu) yang dialami siswa. Disini terlihat sekali peran seorang guru BK untuk mampu mengarahkan remaja menyelesaikan tugas perkembangannya, selain itu guru BK juga diminta mampu membantu siswa menyelesaikan permasalahannya yang berkaitan dengan konsep diri siswa pubertas agar mereka bisa menerima keadaan dirinya sebagaimana mestinya agar KES nya tidak terganggu.

Setelah diketahui konsep diri remaja pada masa pubertas, maka akan terlihat implikasinya dalam layanan yang diterapkan guru BK terhadap remaja pada masa pubertas tersebut. Guru BK dapat menerapkan layananlayanan yang sesuai dengan permasalahan yang dialami oleh siswa tersebut. Jadi dengan diketahuinya masalah konsep diri remaja pada masa pubertas, guru BK dapat berperan dalam membantu siswa dalam menyelesaikan permasalahannya.

Dari latar belakang masalah di atas, fokus dalam penelitian ini sebagai berikut:

1. Bagaimana pengetahuan remaja pubertas tentang perubahan-perubahan yang dialaminya disaat pubertas

2. Bagaimana pengharapan remaja pubertas tentang perubahan-perubahan yang dialaminya disaat pubertas

3. Bagaimana penilaian remaja pubertas tentang perubahan-perubahan yang dialaminya disaat pubertas.

\section{METODOLOGI}

Penelitian ini menggunakan metode kuantitatif dengan pendekatan analisis deskriptif. Populasi penelitian ini adalah siswa yang berada pada masa pubertas di kelas VII SMPN 13 Sijunjung dengan jumlah 110 orang. Penarikan sampel dilakukan dengan teknik purposive sampling, sehingga didapatkan sampel penelitian sebanyak 79 orang.

Alat yang digunakan untuk pengumpulan data dalam penelitian ini adalah kuesioner/angket. Untuk setiap kemungkinan jawaban, kuesioner/angket penelitian menggunakan kriteria lima pilihan jawaban yaitu: untuk pernyataan pada bagian pengetahuan pilihan jawabannya adalah sangat paham, paham, kurang paham, tidak paham, dan sangat tidak paham. Untuk bagian pengharapan pilihan jawabannya adalah sangat berharap, berharap, kurang berharap, tidak berharap, dan sangat tidak berharap. Sedangkan untuk bagian penilaian pilihan jawabannya adalah sangat baik, baik, kurang baik, tidak baik, dan sangat tidak baik. Untuk melihat persentase hasil penelitian, peneliti menggunakan rumus persentase:

$$
P=\frac{f}{n} \times 100
$$

Keterangan:

HASIL

$$
\begin{aligned}
& \mathrm{P}=\text { Persentase } \\
& \mathrm{f}=\text { Frekuensi } \\
& \mathrm{n}=\text { Jumlah responden }
\end{aligned}
$$

Berdasarkan hasil pengolahan data, maka hasil penelitian ini dapat dilihat pada tabel berikut:

Tabel 1. Hasil Penelitian Mengenai Konsep Diri Remaja Pada Masa Pubertas

\begin{tabular}{|l|l|c|c|c|c|}
\hline No & $\begin{array}{l}\text { Konsep diri } \\
\text { remaja } \\
\text { masa pubertas }\end{array}$ & \multicolumn{2}{|c|}{ Laki-Laki } & \multicolumn{2}{|c|}{ Perempuan } \\
\hline \multirow{2}{*}{1.} & Pengetahuan & $\mathrm{P}$ & $\mathrm{T}$ & $\mathrm{P}$ & $\mathrm{TP}$ \\
\cline { 3 - 6 } & $70 \%$ & $30 \%$ & $\begin{array}{c}64,6 \\
\%\end{array}$ & $\begin{array}{c}35,4 \\
\%\end{array}$ \\
\hline \multirow{2}{*}{2.} & \multirow{2}{*}{ Pengharapan } & $\mathrm{B}$ & $\mathrm{TB}$ & $\mathrm{B}$ & $\mathrm{TB}$ \\
\cline { 3 - 7 } & & $\begin{array}{c}66,2 \\
\%\end{array}$ & $\begin{array}{c}33,8 \\
\%\end{array}$ & $\begin{array}{c}64,2 \\
\%\end{array}$ & $\begin{array}{c}35,8 \\
\%\end{array}$ \\
\hline \multirow{3}{*}{3.} & \multirow{2}{*}{ Penilaian } & $\mathrm{B}$ & $\mathrm{TB}$ & $\mathrm{B}$ & $\mathrm{TB}$ \\
\hline & & $\begin{array}{c}64,3 \\
\%\end{array}$ & $\begin{array}{c}35,7 \\
\%\end{array}$ & $\begin{array}{c}63,4 \\
\%\end{array}$ & $\begin{array}{c}36,6 \\
\%\end{array}$ \\
\hline & Rata-rata & $\begin{array}{c}66,8 \\
\%\end{array}$ & $\begin{array}{c}33,3 \\
\%\end{array}$ & $\begin{array}{c}64,1 \\
\%\end{array}$ & $\begin{array}{c}35,9 \\
\%\end{array}$ \\
\hline
\end{tabular}


Dari hasil penelitian, konsep diri remaja pada masa pubertas. Dapat terlihat dari tiga aspek yang diteliti, yaitu pengetahuan, pengharapan, dan penilaian individu terhadap perubahan ukuran tubuh, proporsi tubuh, ciri-ciri seks primer, dan ciri-ciri seks sekunder.

Pengetahuan remaja pada masa pubertas terhadap perubahan-perubahan yang terjadi pada masa puber adalah baik dengan persentase $70 \%$ bagi siswa laki-laki dan $64,6 \%$ bagi siswa yang perempuan. Pengharapan remaja pada masa pubertas terhadap perubahan-perubahan yang terjadi pada masa puber baik dengan persentase $66,2 \%$ bagi siswa laki-laki dan $64,2 \%$ bagi siswa perempuan, sedangkan Penilaian remaja pada masa pubertas terhadap perubahan-perubahan yang terjadi pada masa puber baik dengan persentase $64,3 \%$ bagi siswa laki-laki dan $63,4 \%$ bagi siswa yang perempuan. Jadi dapat dilihat konsep diri secara keseluruhan adalah baik dengan perentase $66,8 \%$ bagi siswa laki-laki dan $64,1 \%$ bagi siswa perempuan.

\section{PEMBAHASAN}

\section{Pengetahuan remaja pubertas tentang perubahan-perubahan yang dialaminya disaat pubertas}

Dari temuan penelitian ditemukan bahwa $70 \%$ siswa laki-laki paham tentang perubahan-perubahan yang terjadi pada masa pubertas. Hal ini menggambarkan bahwa pada umumnya siswa laki-laki yang berada pada masa pubertas, sudah memiliki pengetahuan yang baik tentang perubahan-perubahan yang dialaminya di masa pubertas. Namun demikian 30\% siswa laki-laki tidak paham dengan perubahan-perubahan yang terjadi tersebut. Dan $64,6 \%$ siswa perempuan paham tentang perubahan-perubahan yang terjadi pada masa pubertas. Sedangkan $35,4 \%$ siswa perempuan tidak paham tentang perubahan-perubahan yang terjadi pada masa pubertas.

Dari temuan penelitian di atas dapat dilihat bahwa pengetahuan yang dimiliki oleh siswa laki-laki mencapai $70 \%$ dan siswa yang perempuan $64,6 \%$. Ini menunjukkan bahwa baik siswa laki-laki maupun siswa perempuan paham dengan baik tentang perubahan-perubahan yang dialaminya dalam masa pubertas. Dengan demikian dapat dikatakan bahwa mereka sudah memiliki konsep diri yang baik. Hal ini sesuai dengan yang diungkapkan oleh James F. Calhoun (1995:67) bahwa dimensi pertama dari konsep diri adalah pengetahuan, yang merupakan hal apa yang diketahui tentang diri sendiri. Dalam hal ini pengetahuan individu terhadap terjadinya perubahan yang dialaminya saat puber sangatlah penting. Karena dengan memiliki pengetahuan yang baik terhadap perubahan yang terjadi pada masa pubertas akan membuat individu memiliki konsep diri yang baik dalam dirinya.

Di samping itu dapat juga dilihat bahwa masih ada sekitar 30\% siswa laki-laki dan 35,4\% siswa perempuan yang tidak paham tentang perubahan-perubahan yang dialaminya di masa pubertas. Mereka masih bingung dengan perubahan-perubahan yang terjadi begitu pesat. Hal ini bisa dikatakan wajar mereka alami, karena memang kebanyakan remaja pubertas tidak dibekali dengan pemahaman yang baik sebelum mereka memasuki masa pubertas tersebut. Hal ini senada dengan yang diungkapkan Elizabeth B. Hurlock (1980:194) sebagian besar anak-anak memasuki masa puber tanpa memiliki pengetahuan dan pemahaman mengenai lamanya waktu yang diperlukan untuk menjadi matang atau tentang pola kematangan yang terjadi, akibatnya anak menjadi prihatin bila melihat perubahan tubuhnya. Hal inilah yang biasanya membuat seorang anak memiliki konsep diri yang kurang baik pada masa pubertas

\section{Pengharapan remaja pubertas tentang perubahan-perubahan yang dialaminya disaat pubertas?}

Dari temuan penelitian ditemukan bahwa 66,2\% siswa laki-laki berharap terhadap perubahan-perubahan yang terjadi pada masa pubertas. Hal ini menggambarkan bahwa pada umumnya siswa laki-laki yang berada pada masa pubertas, memiliki pengharapan yang baik terhadap terjadinya perubahan-perubahan tersebut. Sedangkan 33,8\% siswa laki-laki tidak berharap terhadap perubahan-perubahan yang terjadi pada masa pubertas. Dan $64,2 \%$ siswa perempuan berharap terhadap perubahan-perubahan yang terjadi pada masa pubertas. Hal ini menggambarkan bahwa pada umumnya siswa perempuan juga sudah memiliki pengharapan yang baik terhadap terjadinya perubahan-perubahan pada masa pubertas. Sedangkan 35,8\% siswa perempuan tidak berharap terhadap perubahan yang terjadi pada masa pubertas.

Dari temuan penelitian di atas dapat dilihat bahwa pengharapan yang dimiliki oleh siswa laki-laki mencapai $66,2 \%$ dan siswa perempuan 64,2\%. Ini artinya baik siswa laki-laki maupun siswa perempuan yang berada pada masa pubertas berharap terhadap perubahan-perubahan yang terjadi di masa pubertas. Berarti sudah bisa dikatakan bahwa mereka sudah memiliki konsep diri yang baik pada masa pubertas. Hal ini senada dengan 
pendapat Rogers (dalam James F. Calhoun, 1995:71) bahwa dimensi kedua dari konsep diri adalah pengharapan yang ada dalam diri tentang diri seseorang. Dalam hal ini adalah pengharapan terhadap perubahan yang dialami di masa pubertas. Pada saat seseorang mempunyai satu set pandangan tentang siapa dirinya, maka dia juga mempunyai satu set pandangan lain yaitu tentang kemungkinan menjadi seperti apa dirinya di masa mendatang. Atau dengan kata lain dapat dikatakan bahwa setiap orang memiliki harapan bagi dirinya sendiri, dimana pengharapan setiap individu itu berbeda sesuai diri ideal yang di inginkannya. Dan jika pengaharapannya baik maka akan melahirkan konsep diri yang baik pula di dalam dirinya.

Di samping itu dapat juga dilihat bahwa masih ada sekitar 33,8\% siswa laki-laki dan 35,8\% siswa perempuan yang tidak berharap terhadap perubahan-perubahan yang dialaminya di masa pubertas. Ini akan mempengaruhi konsep diri yang dimilikinya, karena tanpa ada harapan tentang seperti apa diri yang diinginkannya, maka mereka tidak akan memiliki pengharapan diri yang ideal. Pengharapan diri yang ideal ini berbeda antara individu satu dengan yang lainnya. Sesuai dengan yang diungkapkan dalam Elizabeth B. Hurlock (1980:201) bahwa pada masa pubertas, setiap individu akan memiliki pengharapan yang berbeda terhadap dirinya, sesuai dengan pandangan ideal diri yang diinginkannya. Seorang individu akan sulit menerima dirinya karena gelisah akibat tubuhnya yang mulai berubah dan tidak puas terhadap penampilannya. Misalnya anak perempuan yang berharap bisa memiliki tubuh yang ramping serta anak laki-laki yang ingin memiliki bahu yang lebar serta tungkai kaki yang lebih berisi.

Calden dalam Elizabeth B. Hurlock

(1980:201) menyatakan bahwa perempuan menginginkan perubahan dari pinggang ke bawah, dan menginginkan bagian-bagian tubuh lainnya lebih kecil (kecuali payudara). Sedangkan laki-laki merasa tidak puas dengan dimensi tubuh dari pinggang ke atas, mereka menginginkan bagian tubuh yang lebih lebar. Dari pendapat di atas jelaslah bahwa pengharapan terhadap diri sendiri sangat berpengaruh terhadap penerimaan diri yang akan membentuk konsep diri dalam diri individu, terutama individu yang sedang berada dalam masa pubertas

\section{Penilaian remaja pubertas tentang perubahan-perubahan yang \\ dialaminya disaat pubertas}

Dari temuan penelitian ditemukan bahwa $64,3 \%$ siswa laki-laki memiliki penilaian baik tehadap perubahan-perubahan yang terjadi pada masa pubertas. Ini berarti bahwa pada umumnya siswa laki-laki sudah menilai baik semua perubahan-perubahan yang terjadi pada dirinya di masa pubertas. Namun demikian 35,7\% siswa laki-laki memiliki penilaian yang tidak baik terhadap perubahan yang terjadi pada masa pubertas. Hal ini menunjukkan bahwa masih ada di antara siswa laki-laki yang berada pada masa pubertas yang memandang bahwa perubahan-perubahan yang dialaminya sebagai sesuatu hal yang buruk. Dan 63,4\% siswa perempuan memiliki penilaian baik terhadap perubahan-perubahan yang terjadi pada masa pubertas. Sehingga bisa dikatakan bahwa pada umumnya siswa perempuan yang berada pada masa pubertas menganggap perubahan-perubahan yang dialaminya sebagai sesuatu hal yang baik bagi dirinya. Sedangkan 36,6\% siswa perempuan memiliki penilaian yang tidak baik terhadap perubahan yang terjadi pada masa pubertas. Mereka masih menganggap bahwa perubahan-perubahan tersebut merupakan hal buruk yang harus mereka alami.

Dari temuan penelitian di atas dapat dilihat bahwa penilaian yang dimiliki oleh siswa laki-laki mencapai $64,3 \%$ dan siswa perempuan $63,4 \%$. Ini artinya baik siswa laki-laki maupun siswa perempuan yang berada pada masa pubertas memiliki penilaian yang baik terhadap perubahan-perubahan yang terjadi di masa pubertas. Berarti sudah bisa dikatakan bahwa mereka sudah memiliki konsep diri yang baik pada masa pubertas. Hal ini diperkuat oleh James F. Calhoun (1990:71) "Bahwasanya dimensi ketiga dari konsep diri adalah penilaian terhadap diri sendiri, dimana seorang individu berperan langsung sebagai penilai tentang dirinya sendiri setiap hari”. Dalam hal ini dapat dilihat dari penilaian seorang individu terhadap perubahan fisik yang pesat yang dialaminya selama masa pubertas berlangsung. Seorang individu yang memiliki penilaian yang baik terhadap perubahan yang dialaminya. Akan mampu menerima dirinya dengan baik sehingga akan menghasilkan konsep diri yang baik pula dalam hidupnya.

Di samping itu dapat juga dilihat bahwa masih ada sekitar 35,7\% siswa laki-laki dan 36,6\% siswa perempuan memiliki penilaian yang tidak baik tentang perubahan-perubahan yang dialaminya di masa pubertas. Hal ini biasa terjadi pada remaja di masa pubertas. Sebagaimana menurut Elizabeth B. Hurlock (1980:197) sebagian anak melewati masa puber tanpa mengembangkan konsep diri yang kurang menyenangkan. Hal ini 
salah satunya disebabkan oleh penilaian oleh individu itu sendiri terhadap bentuk tubuhnya yang mengalami perubahan di masa pubertas.

\section{Implikasi dalam Layanan Bimbingan dan Konseling}

Sebelum menentukan layanan yang diberikan kepada, hal yang paling utama dilaksanakan adalah need assessment atau studi kebutuhan. Studi kebutuhan sangat diperlukan dalam menentukan kebutuhan atau masalah yang dialami siswa. Studi kebutuhan merupakan suatu usaha untuk merencanakan ketepatan layanan yang diberikan agar sesuai dengan kebutuhan siswa asuh.

Studi kebutuhan diawali dengan memberikan dan memanfaatkan kegiatan pendukung yang ada di BK, dalam penelitian ini dapat digunakan angket penelitian. Dari hasil studi kebutuhan ini nanti akan terlihat hal-hal yang dialami oleh siswa. Layanan Bimbingan dan Konseling diberikan untuk mengentaskan masalah yang dilami siswa.

Layanan BK yang diberikan disesuaikan dengan masalah yang dialami siswa. Dalam penelitian ini, layanan BK diberikan untuk mengubah konsep diri remaja pubertas dari Tidak Baik (TB), Kurang Baik (KB) dan Cukup Baik (CB) ke arah yang lebih Baik (B) atau Sangat Baik (SB).

Setelah diketahui permasalahan konsep diri yang dialami siswa dalam menghadapi masa pubertas, selanjutnya direncanakan jalan keluar yang diberikan untuk mengentaskan masalah siswa tersebut berupa pemberian layanan BK. Adapun layanan yang diberikan berkenaan dengan masalah konsep diri remaja pubertas adalah:

A. Layanan informasi

Layanan informasi merupakan layanan yang diberikan kepada individu dengan memberikan informasi yang dibutuhkan individu (Prayitno, 2004: 3). Layanan informasi bisa diberikan dengan format klasikal dan diberikan untuk memberikan jalan keluar dari masalah yang banyak dialami oleh siswa.

Berdasarkan temuan penelitian, maka materi layanan informasi yang mungkin bisa diberikan adalah sebagai berikut : a)perkembangan manusia, b)masa remaja dan masa pubertas, c)perubahan-perubahan fisik yang penting bagi remaja di masa puber, serta d)sikap yang diperlukan dalam menghadapi perubahan fisik di masa puber.

B. Layanan konseling perorangan

Layanan konseling perorangan diberikan kepada siswa yang mengalami masalah tertentu dan tidak perlu dialami oleh banyak siswa. Format pelaksanaan layanan konseling perorangan bisa dengan menunggu klien datang ke konselor, namun bisa juga dengan cara memanggil siswa yang mengalami masalah tertentu.

C. Layanan konseling kelompok

Layanan konseling kelompok merupakan layanan yang diberikan dengan format kelompok dengan memanfaatkan dinamika kelompok dalam mebahas dan membantu mencarikan jalan keluar dari masalah yang dialami anggota kelompok. Layanan konseling kelompok diberikan kepada kelompok siswa yang mengalami masalah yang sama. Layanan konseling kelompok dipilih untuk mengentaskan masalah yang dialami siswa pubertas dalam menghadapi perubahan yang dialaminya pada masa pubertas. Jadi berbeda dengan layanan informasi dan layanan penguasaan konten, layanan konseling kelompok hanya dialami oleh beberapa siswa.

D. Layanan bimbingan kelompok

Seperti halnya konseling kelompok, layanan bimbingan kelompok bisa diterapkan dengan format kelompok. Bimbingan kelompok diberikan dengan menggabungkan siswa yang mengalami masalah dengan yang tidak mengalami masalah dalam menhadapi masa pubertas. Hal ini dimaksudkan agar dengan dinamika kelompok bisa membantu siswa yang mengalami masalah tersebut.

Topik yang diberikan dapat berupa topik tugas ataupun topik bebas. Adapun jika bimbingan kelompok dilakukan dengan topik tugas, maka topik yang mungkin dibahas adalah sebagai berikut : a)seks bebas, b)pertumbuhan dan perkembangan manusia, serta c)perubahan-perubahan fisik penting bagi remaja pada masa puber 


\section{PENUTUP}

Berdasarkan penelitian yang telah dilakukan dapat disimpulkan bahwa secara umum konsep diri remaja pada masa pubertas adalah baik. Hal ini diketahui dengan melihat pengetahuan, pengharapan, dan penilaian siswa terhadap perubahan ukuran tubuhnya, proporsi tubuh, ciri-ciri seks primer, serta ciri-ciri seks sekunder yang dialaminya pada masa pubertas.

Berkenaan dengan temuan penelitian, peneliti mengemukakan beberapa saran kepada beberapa pihak yaitu: Bagi siswa yang berada di masa pubertas, melalui penelitian ini dapat mengetahui permasalahan yang mereka alami dalam menghadapi masa pubertas. Selanjutnya, siswa bisa berusaha menyelesaikan permasalahannya melalui berbagai layanan BK yang sesuai. Kepada personil sekolah, melalui penelitian ini terlihat masalah yang dialami siswa dalam menghadapi masa pubertas dan diharapkan bisa membantu sebagai bahan acuan dalam menerapkan dan meningkatkan program sekolah untuk siswanya.terakhir kepada guru BK, sebagai masukan untuk menyusun program pelayanan bimbingan dan kegiatan pendukung bimbingan konseling yang sesuai dengan kebutuhan dan perkembangan siswa sehingga siswa mampu menghadapi dan melalui masa pubertasnya dengan baik

\section{DAFTAR PUSTAKA}

Anas Sudijono. 2011. Evaluasi Pendidikan. Jakarta: Raja Grafindo Persada

A.Muri Yusuf. 2005. Metodologi Penelitian. Padang: UNP Press

Elida Prayitno. 2006. Psikologi Perkembangan Remaja. Padang: Angkasa Raya

Elizabeth B.Hurlock. 1980. Psikologi Perkembangan. Jakarta: PT. Aksara Pratama

James F. Calhoun. 1995. Psikologi tentang Penyesuaian. Semarang: IKIP Semarang Press

John W. Santrock. 2007. Remaja. Jakarta: PT Gelora Aksara Pratama

Mohammad Ali, asrori. 2009. Psikologi Remaja. Jakarta: PT Bumi Aksara

Prayitno. 2004. Buku Seri Layanan Bimbingan Konseling. Padang: BK FIP UNP 